Please do not remove this page

RMIT

UNIVERSITY

\title{
Employment systems in small firms: A multilevel analysis
}

Verreynne, Martie-Louise; Parker, Polly; Wilson, Marie

https://researchrepository.rmit.edu.au/esploro/outputs/9921863618701341/filesAndLinks?institution=61RMIT_INST\&index=null

Verreynne, M.-L., Parker, P., \& Wilson, M. (2013). Employment systems in small firms: A multilevel analysis. International Small Business Journal, 31(4), 405-431. https://doi.org/10.1177/0266242611401445

Document Version: Published Version

Published Version: https://doi.org/10.1177/0266242611401445

Repository homepage: https://researchrepository.rmit.edu.au

(C) The Author(s) 2011

Downloaded On 2023/04/26 23:16:36 +1000

Please do not remove this page 


\section{Employment systems in small firms: A multilevel analysis}

\author{
Martie-Louise Verreynne and Polly Parker \\ University of Queensland,Australia
}

International Small Business Journal
$I-27$
C The Author(s) 201 I
Reprints and permission: sagepub.
co.uk/journalsPermissions.nav
DOI: 10.1 I $77 / 02662426$ I I 40 I 445
isb.sagepub.com

(SAGE

\title{
Marie Wilson
}

Griffith University,Australia

\begin{abstract}
This exploratory study draws upon the perspectives of employees and managers from 50 small Australian firms to build a more complete and nuanced view of the interaction of human resources and capabilities with firm performance. Specifically, it uses a mixed methods multilevel design that elicits employee perspectives of employment systems and chief executive officer (CEO) assessments of firm performance. Results show that higher performing firms had better rated employment systems, with a cluster of human resource practices which included greater informality, employee engagement and participation. The views of employees were more discriminating and diagnostic than those of CEOs. The article discusses the implications of these findings for the study of employment systems and human resource management in small firms.
\end{abstract}

\section{Keywords}

employment systems, high-performance work systems, human resource management, performance, small firms

\section{Introduction}

Much attention has been afforded to the critical factors that underpin performance in small firms, differentiating those who thrive (e.g. Chan et al., 2006; Garnsey et al., 2006; Hansen and Hamilton, 2011) or fail (e.g. Hartarska and Gonzalez-Vega, 2006). Effectiveness in firms builds upon alignment between firm strategy and the management of people, a strategic approach that is often highlighted in the human resource management (HRM) literature (e.g. Boxall and Purcell, 2000). Despite this, our understanding of HRM and employment relations in small firms remains somewhat limited (Cardon and Stevens, 2004). Claims that HRM practices within firms correlate with measures of performance (Way, 2002) are confounded by inherent diversity: 'practice' means different things in

\section{Corresponding author:}

Martie-Louise Verreynne, University of Queensland Business School, University of Queensland, St Lucia, Brisbane, QLD 4072, Australia

Email: m.verreynne@business.uq.edu.au 
small and large firms (Edwards and Ram, 2010). Models of employment systems in large firms may be of much less value in enhancing firm performance in small firms, which often have lower levels of expertise and fewer resources (Cardon and Stevens, 2004). The scarcity of resources drives diversified and divergent employment systems from the initiation of new ventures through their early growth and development (Baron et al., 1996, 1999). Furthermore, contextualizing small firm human resource (HR) practices provides an opportunity to build upon unique resources, informal employment systems and distinctive employee capabilities that underpin firm performance (Edwards and Ram, 2010).

The purpose of this article is to enhance the understanding of employment practices as contributors to performance in small firms, with an emphasis on the employee perspective. Using a mixed methods research design, the study explored how employees perceived their contribution to firm performance. It also uses chief executive officer (CEO) perceptions of performance to discriminate between high- and low-performing firms: by comparing themes in both datasets we identified unique patterns of managerial and HR capabilities for each group. Finally, the article takes a multilevel view by comparing both $\mathrm{CEO}$ and employee responses.

\section{Employment systems and small firms}

It is argued that effective management of HR is one of the most crucial problems facing small firms (Deshpande and Golhar, 1994). This has led to an increased interest in analysing their employment systems (Cardon and Stevens, 2004; Marlow et al., 2010; Tanskey and Henemann, 2003). Firm size is related to sophistication and formalization of employment systems (Hornsby and Kuratko, 1990; Rutherford et al., 2003). In larger firms, a strategic HRM approach is based on a resource-based view of internal and external fit to enhance performance (Allen and Wright, 2007), and an analysis of formal processes that leverage employee capability to maximize productivity (Wright et al., 1994).

While there are common HR issues to be addressed by all firms (Deshpande and Golhar, 1994; Hornsby and Kuratko, 1990), within smaller firms, formal policies and practices are rare and indeed, given their context, extending 'existing models of HR to small firms would not be meaningful' (Cardon and Stevens, 2004: 318). These informal practices enable flexibility and responsiveness, affording competitive advantage that may be endangered by premature formalization (Ciavarella, 2003; Edwards and Ram, 2010). The cost of more formalized HR structures also may undermine productivity gains (Sels et al., 2006). So, rather than drawing from models designed for large firms, small firms are advised increasingly to generate their own models and systems that align business goals (Boxall and Purcell, 2000; Henemann and Tanskey, 2002) with employee capabilities (Bowen and Ostroff, 2004; Cardon and Stevens, 2004). Thus, distinctive models may arise to support firm success, similar to the research on the CEO as the architect of small firm employment systems (Baron, et al., 1996, 1999; Ho et al., 2010).

Research specifically exploring employment systems and HR practices in small firms remains relatively scarce (e.g. Carlson et al., 2006; Mazzarol, 2003; Welbourne and Andrews, 1996), with even less focused upon strategy, HR practices and small firm performance (Henemann, et al. 2000; Hayton, 2003). Adopting a systems perspective is encouraged (Drummond and Stone, 2007): that is, a broader approach to small firm employment systems that incorporate institutional and environmental factors as well as HR practices at the strategic and functional levels (Osterman, 1987). The focus is then on the context rather than describing the specific practices that might signal a particular HR approach (Marlow, 2006). Increasingly, the approach linking broader employment systems to firm performance is based on ongoing theoretical and empirical work in the area of high-performance work systems (HPWS) (Huselid, 1995). HPWS are clusters of HR practices and 
organizational development outcomes that reportedly change employee behaviours, such that they that add value to the firm (see Wood and Wall, 2007 for a review of this literature). HPWS has empirically linked clusters of practices to organizational performance through a causal chain of mediating variables (Guest, 2001; Macky and Boxall, 2007; Way, 2002). Mediators include employee skill development, collaborative workplace problem-solving and an emphasis on employee commitment and citizenship behaviour (Colvin et al., 2001). However, empirical evidence suggests that there can be significant variability among firms in the practices included in the performance-enhancing employment system and, furthermore, that the systems evolve as firms grow and change (Drummond and Stone, 2007).

The application of HPWS principles to the employment systems and success of small firms has emerged only recently (Carlson et al., 2006). However, employment system characteristics, including organizational culture, shared values and behavioural norms, are not only fundamental to the success of small firms but also to the success of the policies and practices focused upon overall competitive advantage (Drummond and Stone, 2007). Our study extends research on employment system contributions to small firm success by identifying the differences between high- and lowperforming small firms, based on a range of employment practices.

\section{Integrating multiple perspectives}

Reporting on small firms generally explores the concerns, assessments and strategic choices of founders, owner-managers and management teams (McGee and Sawyerr, 2003; Herbane, 2010; Vyakarnam and Handelberg, 2005). Typically, managerial perspectives dominate these findings (Marlow et al., 2010). This focus is understandable, as managers are responsible for industry configurations (Web and Pettigrew, 1999), organizational strategies, processes and resources (Verreynne and Meyer, 2010), and have to be knowledgeable regarding firm performance (Galbreath and Galvin, 2006, 2008). Such perspectives on firm performance are particularly important in the small firm sectors, where objective performance data is not commonly available (Galbreath and Galvin, 2006, 2008). However, the bias from an exclusive focus on managerial views has been the subject of sustained critique (e.g. Macky and Boxall, 2007). There are potential problems with measurement error and the possibility that managerial opinion is an inaccurate representation of events (Gerhart et al., 2000; Purcell, 1999).

The voice of the owner/manager or CEO is one of many, yet the perspective and interests of the employee remains 'relatively neglected' (Edwards and Ram, 2010: 525) and largely absent in the empirical literature of small firm performance (Cassell et al., 2002; Duberley and Walley, 1995), particularly in research on the links between HR practices and firm performance (Appelbaum et al., 2000; Guest, 2002). It is simply impossible to know from existing manager-focused research whether any or all employees experience organizational HR practices similarly to managers (Ramsay et al., 2000). This creates a gap in our knowledge regarding the contributing factors to small firm performance, leaving employees with valuable insight into informal employment structures excluded from the research agenda.

One notable and welcome exception is Chang's (2005) empirical study eliciting employee perceptions of HR effectiveness. Generally, employee views of the employment relationship have diverged from those of managers (Grant and Shields, 2002; Tsui and Wang, 2002), particularly with regard to issues of voice (Wood and Wall, 2007), HR management competencies (Graham and Tarbell, 2006), empowerment (Greasley et al., 2008) and autonomy (Darr, 2003). Recent advances further link organizational climate and shared employee perceptions both conceptually (Bowen and Ostroff, 2004) and empirically, through a cross-level analysis of managers and employees (Takeuchi et al., 2009). To add 
to the extant literature, this article reports on the perspectives of employees on the HR strategies and practices of small firms and their contribution to performance, as explained in the following section.

\section{Method}

\section{Research design}

This study compared the dynamics of firm success from multiple perspectives on the policies and practices within the sample firms. We adopted a multilevel survey-based design to overcome the limitations of common source and common method variance (Podsakoff et al., 2003). Our design also allowed for comparison of practices in high-and low-performing firms, facilitating performance differential analysis.

Employees and CEOs from 50 small firms responded to survey questions on strategy and human capabilities that facilitate firm performance. Two separate questionnaires were used, both comprising Likert scales and open-ended questions. The focus in this study was upon the open-ended responses. First, employees at all organizational levels, except the CEO (usually the owner and/or manager of the small firm) were asked to elaborate management practices and policies, including those associated with employment systems. Second, both CEOs and employees commented on the systems and dynamics of firm success. Third, CEOs offered their assessment of firm performance. The questions for both surveys were developed by a panel including industry experts and the researchers, thus drawing on both professional expertise and relevant disciplinary literatures. The coded data and representative quotes were reviewed by all three authors, each providing a differential disciplinary lens. We cross-checked interpretations as the data analysis progressed and our explanatory framework developed and evolved. The sample and the two survey instruments used are described below.

\section{Sample and data collection}

The data were gathered from 50 small Australian firms (defined as those firms employing fewer than 100 employees) in June 2008. The sample reflected a geographical spread of firms throughout Australia, with more than 90 percent from the more populous east coast states (Queensland $-40 \%$, New South Wales - 28\%, Victoria - 24\%). Consistent with Australia's industrial demography, small service sector firms made up the majority of the survey $(84 \%)$, with lesser representation from retail or wholesale (10\%) and manufacturing (6\%). The CEO survey was completed by every CEO from the participating firms. A total of 112 second and subsequent level managers and 498 employees from other organizational levels completed the employee questionnaire for a total of 610 participants (hereafter employees). Participants could select either paper-based or online versions. Of the sample, 62 percent of employees were female and 38 percent were male. Of the employees, 82 percent held general line and support roles and 18 percent were supervisors or second level managers. Firms were recommended by our industry partner. ${ }^{1}$ Once chosen, 15 to 20 employees per organization were randomly selected to complete the questionnaire. On average 12 staff members per firm completed the survey, for a response rate of between 60 and 80 percent per firm.

The CEO survey included six broad, open-ended questions on HR practices and employment systems, relating to quality of planning, partnerships, strategic alignment, employee contributions and employee results. A scale to assess firm performance was included, with 20 questions designed to provide a composite index of operational success. These focused upon: 
- organizational strategy;

- managerial efficiency;

- staff performance;

- quality of HR;

- $\quad$ skills, knowledge and technical ability;

- procedural consistency;

- meeting client expectations;

- maintaining standards;

- financial results; and

- customer service.

This approach reflects previous studies, which used senior management assessments of firm performance to examine strategy and performance (Clark, 2002; Dess et al., 1997; Galbreath and Galvin, 2006; Glancey, 1998; Lebas and Euske, 2002). The use of multiple measures of performance - including goals, aspiration levels, reputation, public image, goodwill, commitment and satisfaction of employees, overall performance and stakeholder satisfaction - is prevalent in the literature on small firm performance (Brown and Laverick, 1994; Rockmore, 1996). Questions had a range of scores from $1=$ a problem area to $5=$ an area of strength. Responses to the fivepoint Likert scale were used to divide firms into high and low performers (index ranged from 47-100, median =67). Following Knight (2000), the median was used as the point of division.

The employee survey focused on employee satisfaction with firm issues in nine areas. Thirty questions covered teamwork, communication, management and leadership, pay and rewards, training and development, work design and environment, planning and strategy, customer focus and culture (see the Appendix). These areas are similar to those used in the Australian Workplace Survey (JRA, 2008), differing only in the inclusion of 'customer focus' and omission of 'employee engagement'.

\section{Data management}

Following Corley and Gioia (2004) we took several steps to manage the data and analysis to ensure trustworthiness. First, we used third-party data collection through an anonymous, paper-based or online survey. We also coded the open-ended questions of the data without prior knowledge of firm performance. Second, data exploration was undertaken with Leximancer (see below) to gain an initial understanding of the data, using lexical algorithms (Smith, 2003). First-order concepts and second-order themes were identified without introducing researcher bias at this early stage. Third, to increase precision and ensure maximum reliability, a further analytical step explored the data manually, noting potential concepts and themes using a content analytical approach, as suggested by Kabanoff and Brown (2008). Using these similar open-coding structures, Fourth, we then worked iteratively with Leximancer to use the themes and concepts identified in both previous stages to develop concept maps that reflected the natural language structures of the respondents. Combined use of both software and manual analytical approaches provided a robust basis for clearly delineating concepts, themes and aggregate dimensions. This process was iterative, until the coding system as presented in Table 1 emerged.

Leximancer is a text analytical software package (Smith, 2003) which conceptually analyses text data using the principles of content analysis. It uses ontological relativity and dynamics to 
assemble bits of information to structure and evaluate concepts (Cummings and Daellenbach, 2009). Words are combined to form concepts (thematic analysis) and identify relationships (semantic analysis) between concepts. A 'concept map' displays the main concepts in the text data, depicting the relationships through visual summaries of concepts and their co-occurrences - similar to a mind map. It uses three indicators - shading, closeness and centrality - to explain the information analysed (Cummings and Daellenbach, 2009). Frequency is presented by the boldness or darker shading of the text. Concepts that occur in similar semantic contexts form clusters or themes on the concept map. Therefore, closeness indicates that concepts occurred within a set range within the data (in our analysis within the response from a single employee). Centrality indicates the connectedness of a concept, thereby indicating the relational characteristics (semantic context) (see the concept 'helpful' in the Findings section).

Kabanoff and Brown (2008) highlight several advantages of fully automated data-analysis, such as that undertaken with Leximancer and its objective algorithm holds over other methods, including less time-intensive, identification of frequently occurring themes with co-occurring themes and their 'inherently disambiguous' results (2008: 155). Important for our purpose is the ability of these methods to be used for both exploratory and content analyses. Despite demonstrated validity and reliability (e.g. Cummings and Daellenbach, 2009; Grech et al., 2002; Middleton et al., 2011; Smith and Humphreys, 2006), the algorithm used during the learning phase may produce results that are of limited value for the desired purpose (Davies et al., 2006). However, Grech et al. (2002) and Ohl (2008) report that Leximancer analysis and manual coding of the same data found no significant differences. Comparing 13 text analytical software packages, including NVivo and Leximancer, Ohl (2008) concludes that Leximancer is reliable and provides the opportunity to do exploratory and confirmatory analyses. Similar to our approach, he also used manual analyses to further enhance trustworthiness. Leximancer analysis is reliable in two ways: namely, stability and reproducibility. Stability is equivalent to intercoder reliability: that is, when the data are processed and reprocessed, the results are highly consistent. The ability to reproduce is shown in Leximancer's ability to classify text in the same manner, no matter how many times the analysis is repeated, constructing a stochastic concept map (Smith and Humphreys, 2006).

\section{Data analysis}

We analysed the qualitative open text data from six questions in the CEO survey and 30 questions in the employee survey, and supplemented our qualitative analysis with ratings data from the survey. Finally, firms were divided into two groups according to the performance index in the CEO survey. There were 24 higher and 26 lower performing firms. A comparison of the high- (24) and low- (26) performing firms revealed no significant differences in terms of demographic characteristics, or any differences between the CEOs in these groups with respect to their assessment of employment systems. However, employees in high- and low-performing firms held clearly different views, as the next section illustrates.

\section{Findings}

The findings are presented in five steps. First, we present a thematic and semantic exploration of the employee data. Second, a more structured content analysis of the same data follows, which identifies the views of these respondents on employment systems. Third, the employee data from higher and lower performing firms are compared along the same themes. Fourth, a comparison of CEOs' views with those of employees is presented, in order to highlight differing perceptions of employment systems. Fifth, the theoretical underpinnings of the data are highlighted. 


\section{Initial findings from thematic and semantic exploration}

The first step focused on the wide range of business-related words used by the respondents and identified from the exploratory Leximancer analysis. These first-order concepts comprised 75 percent of the total identified: the most frequent (considered to be most important) included work $(27 \%)$, business $(12.5 \%)$, staff $(22.9 \%)$, staff training $(16.6 \%)$, team $(12.5 \%)$ and role $(10.4 \%)$. Concepts such as communication, feedback and learning ranged between 5 and 10 percent. Other first-order concepts included culture, career development and related performance management activities, including reward and recognition. The distance between concepts on the map reveals the strength of links. The central first-order concept (see Figure 1) was 'helpful', with strong associations with most other concepts on the map. Help is multifaceted in its use: relating to helping others, helping the organization and including support in work-related endeavours. The thesaurus developed from the data showed that 'helpful', 'help', 'helping' and 'support' all occurred in the same semantic context - that is, they were synonymous. The centrality of this theme provides a starting point for our analysis.

\section{Content analysis of employee data}

The second analytical step was to derive other first-order concepts using Leximancer (summarized in Table 1 below). Using a covariance matrix, Leximancer clustered the first-order concepts into themes, each aggregating two to five concepts and represented by labelled circles in Figures 1 and Figure 2. Additionally, we reviewed these clusters manually to increase face validity of the emergent themes. For example, the map derived from CEO data (Figure 2) shows 'staff' as the central theme, aggregating the first-order concepts of staff, results and needs. Leximancer uses natural language, so the theme is often titled by the most-used word in the aggregation. In this two-pronged approach we reviewed the transcripts from which the first-order concepts were derived and adopted more academic terminology to facilitate later mapping against the extant literature. In most cases we used the respondents' original words of (e.g. 'training'), consistent with Leximancer. However, in some cases a word was used so often that clarification of meaning was required. For example, the reference to 'work' followed by 'our level of communication needs to improve dramatically', led to a second-order theme (communication) to supersede work, and thus enhance clarity. Following Corley and Goia (2004), the thematic responses were checked against the original transcripts to assess co-location within employee comments. Clear patterns emerged that led to the establishment of aggregated dimensions, including knowledge-sharing, communication, collegiality, training, employee involvement, trust, teamwork, role flexibility, work practice flexibility, role requirements, culture, career development, feedback, rewards and recognition, clarity of expectations, commitment and satisfaction. Table 1 shows the first-order concepts, representative quotes to illustrate them and the subsequently derived themes.

\section{Comparing higher and lower performing firms}

The third analytical step differentiated higher from lower performing firms based on managerial perceptions of performance. We analysed the responses of 237 employees from higher performing firms (average size $=10$ employees) and 375 from lower performing firms (average size $=14$ employees). The differences in number reflect the larger average size of lower performing firms that completed the survey. Similar themes emerged from our secondary analysis of all employee responses, yet distinctive patterns for both higher and lower performing small firms were evident. 


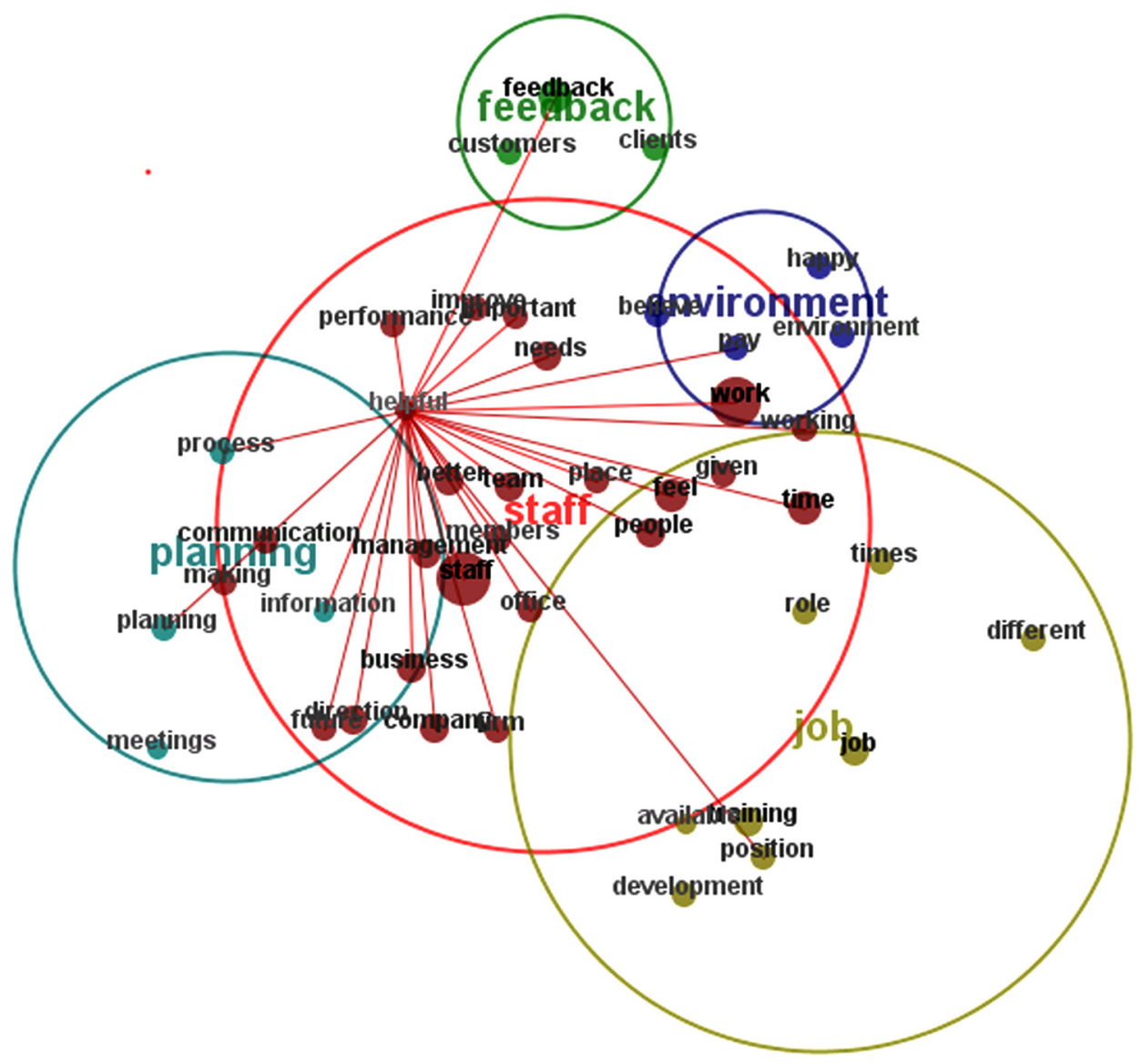

Figure I. Key Concepts Identified by Employees Note: All concepts shown, theme size at $60 \%$

These differences were confirmed through $t$-tests for differences of means of responses from employees of higher and lower performing firms to questions rated on Likert scales. The $t$-tests indicated that employees from higher performing firms were significantly more positive on 29 of the 30 questions relating to management and employment practices (see the Appendix for a summary of questions).

These differences were confirmed by qualitative data analysis. For example in higher performing firms, teamwork was highlighted, and happiness as an aspect of organizational life and a rationale for commitment emerged for the first time. In lower performing firms, communication was identified as a negative issue and unfairness emerged as an issue for the first time. When these distinctive aspects emerged, we revisited the transcripts for specific examples to illustrate differences between higher and lower performing firms. Exploration of sources of firm performance revealed frequent correspondence between the naturally emerging attributions of employees with the key practices from the HPWS and organizational performance literature (Cooke, 2001). Table 1 summarizes the practices identified as key drivers by employees and their HPWS nomenclature. 


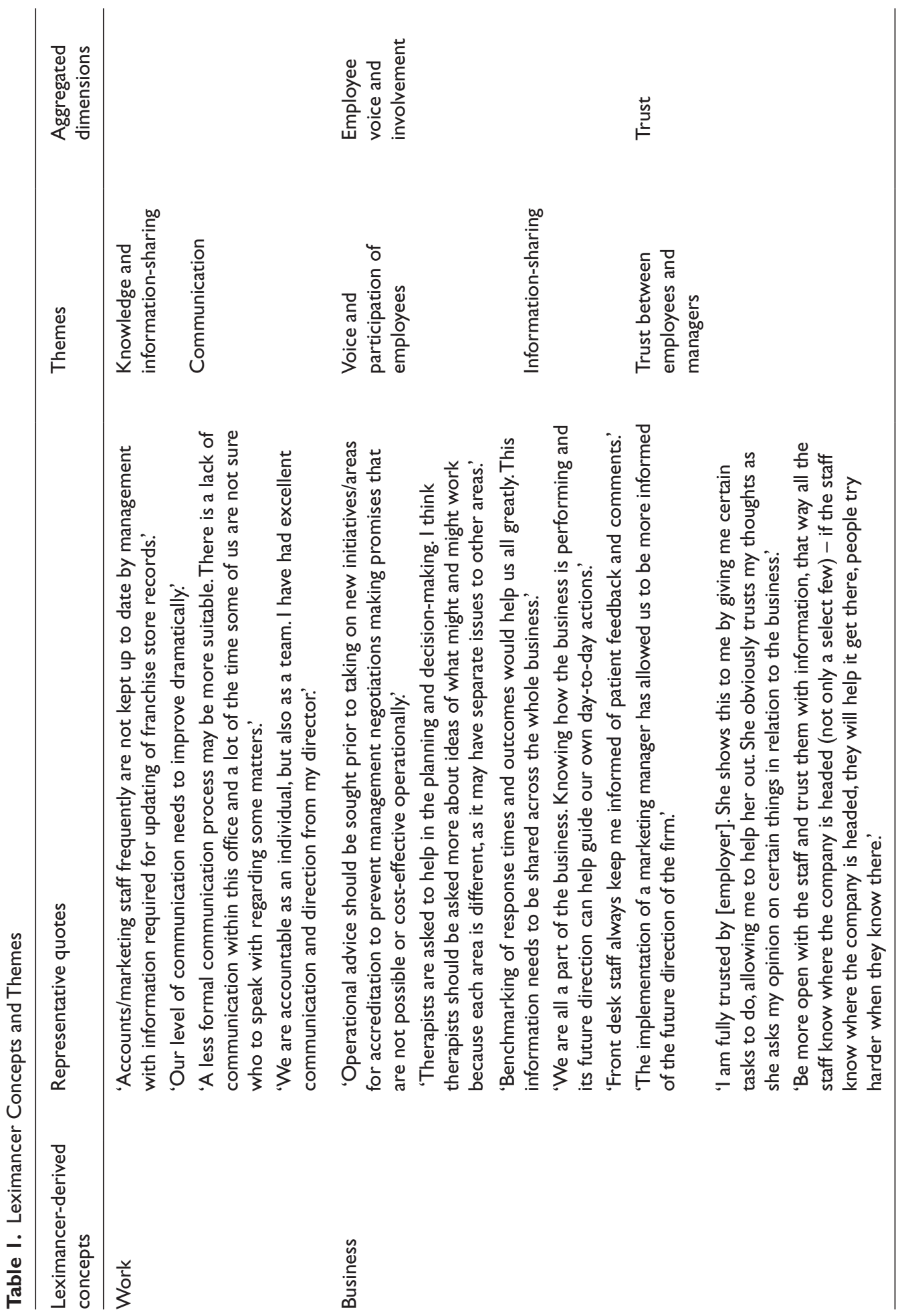




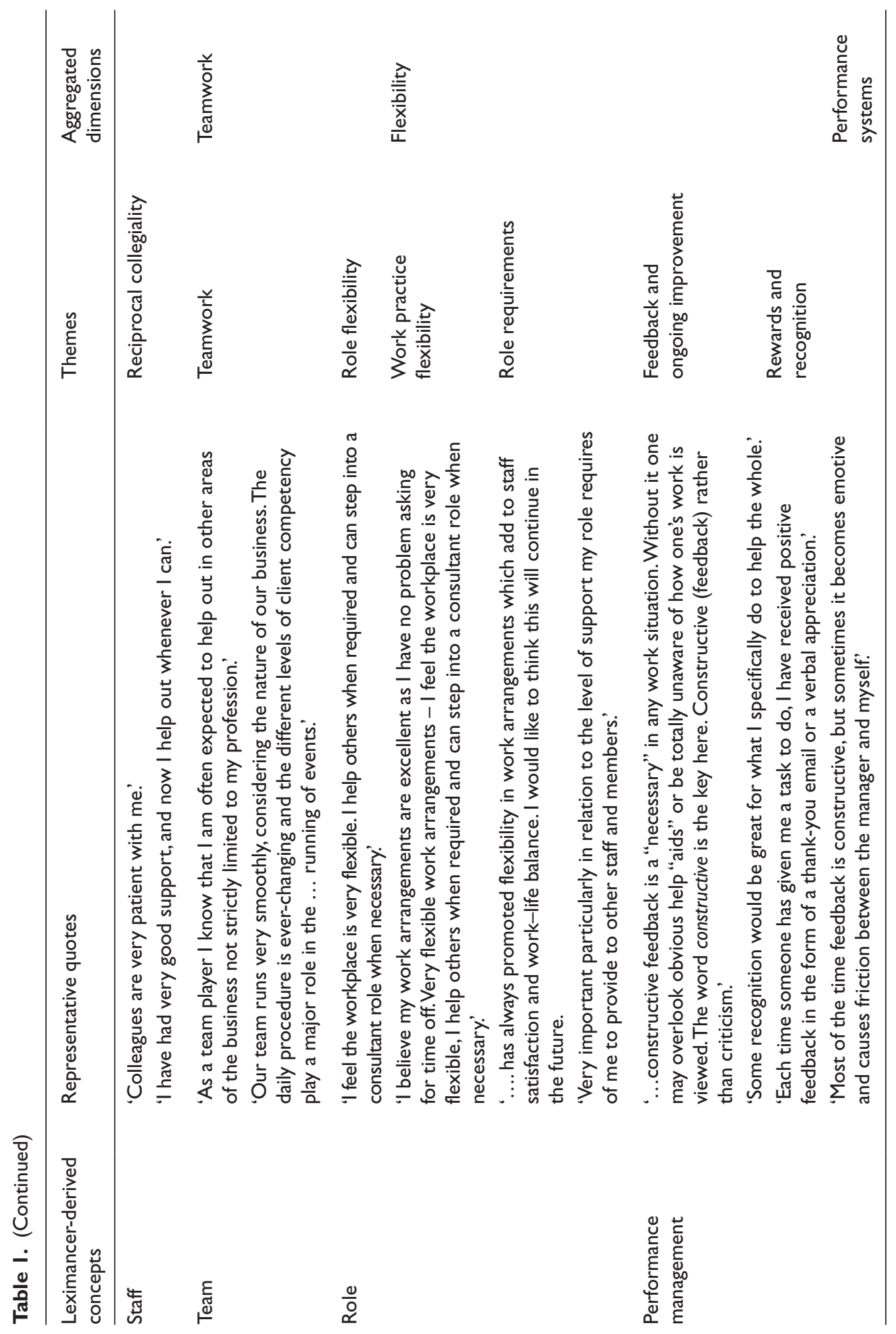




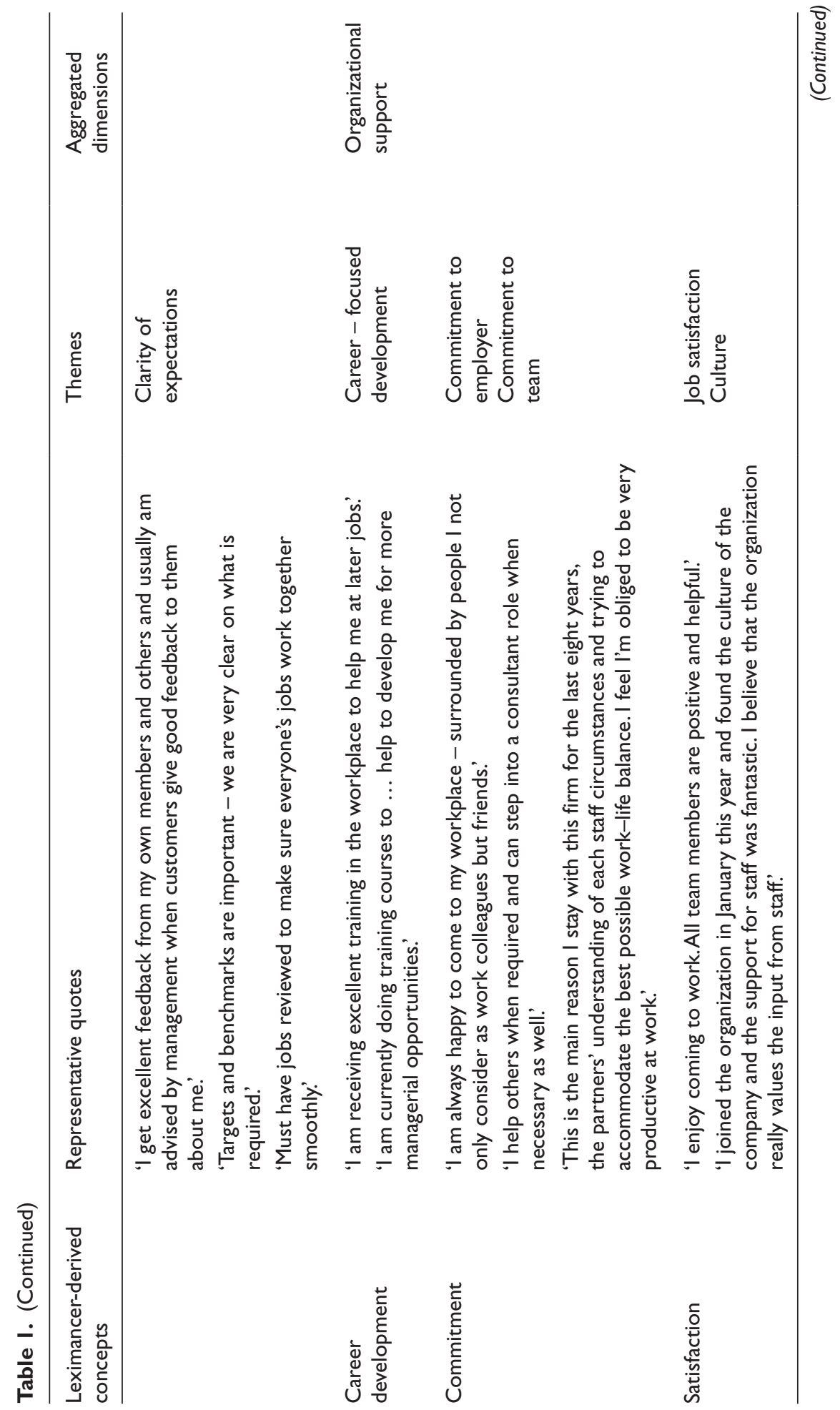




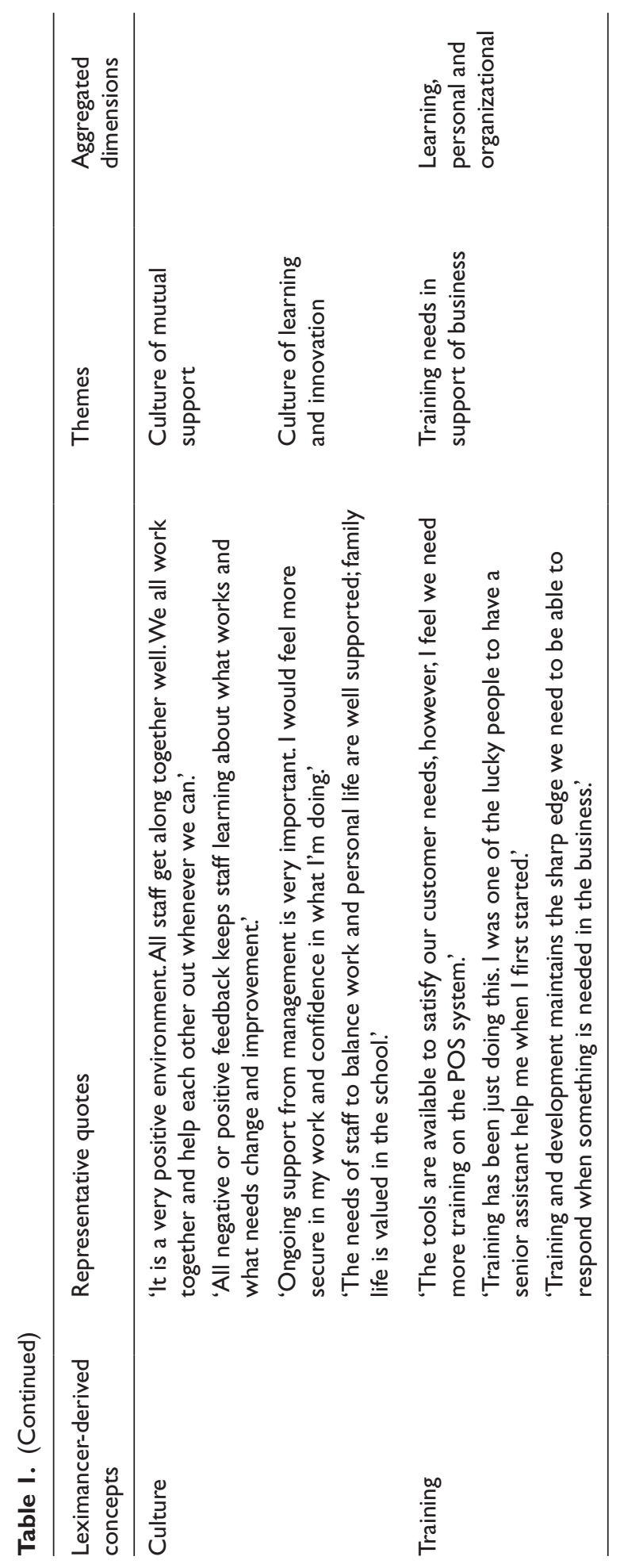




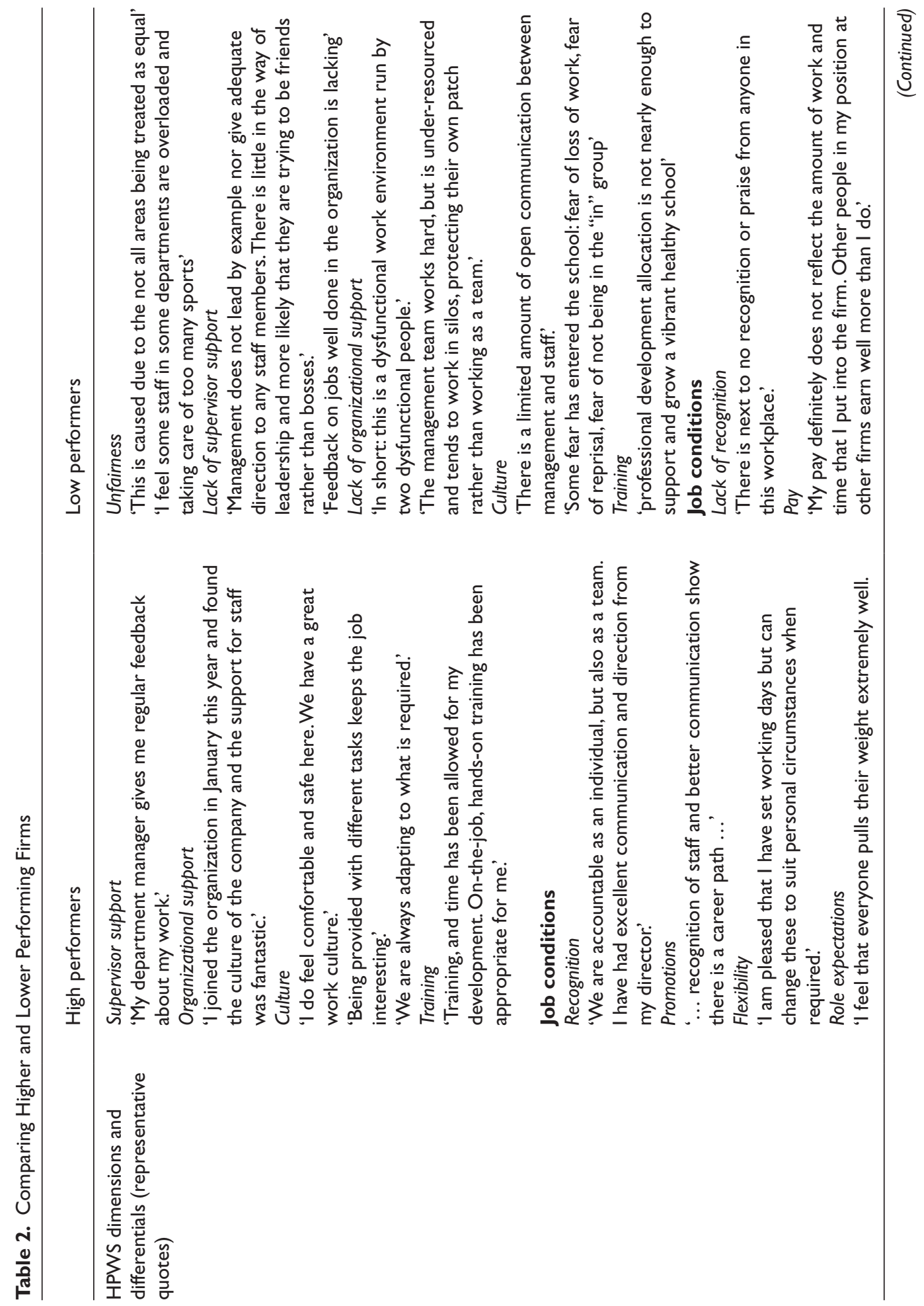




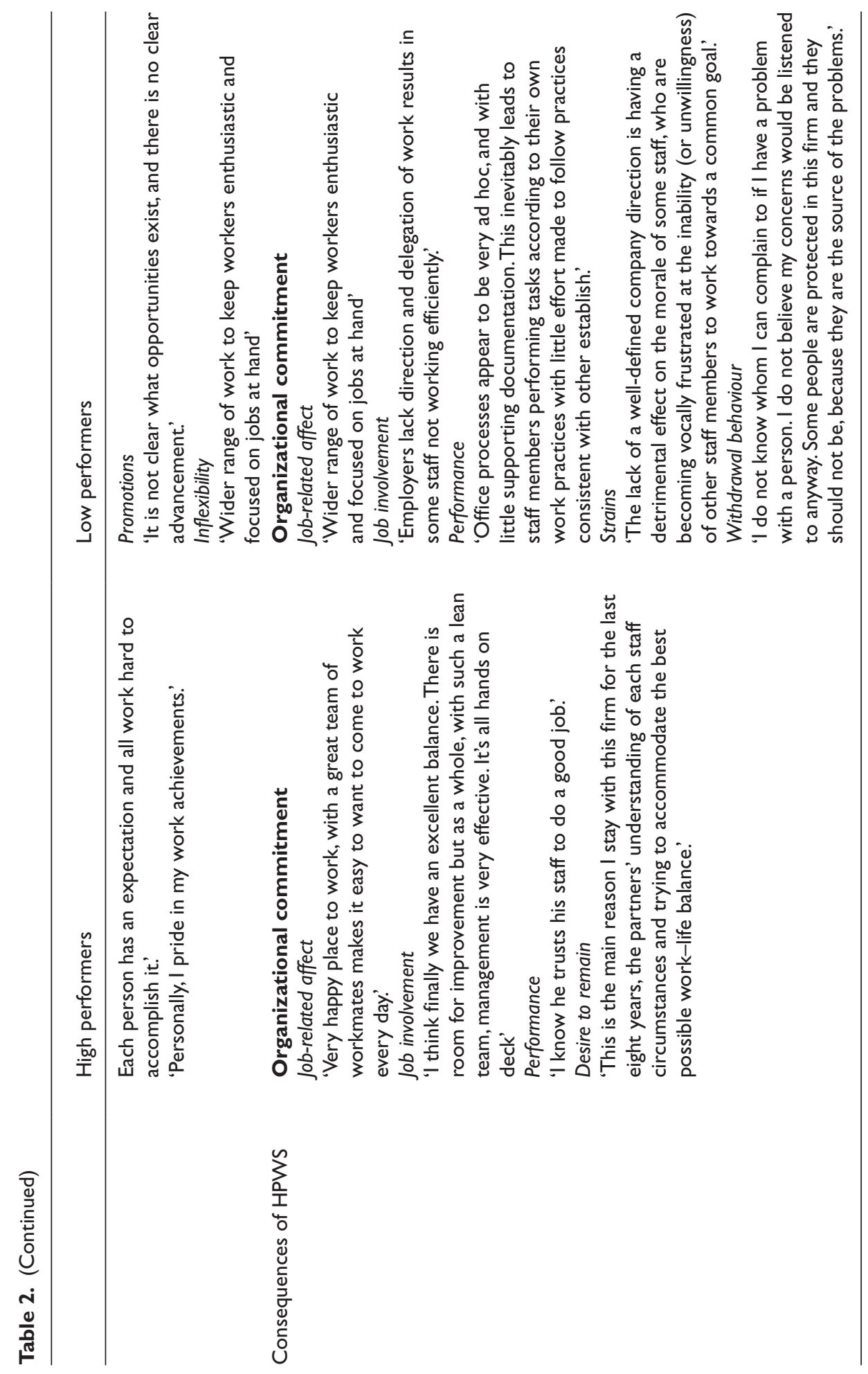


Such distinctive aspects were characterized also by polarization of comments between performance groups (see Table 2). For example, where fairness was mentioned by employees of higher performing firms, the opposite (unfairness) was mentioned in lower performing firms. Moreover, views of the organizational environment differed, with flexibility and enjoyment surfacing in higher performing firms, and fear and lack of communication in lower performing firms. In each case, employees in higher performing firms reported that they were engaged, contributing and committed, and that the drivers are the types of practices, policies and systems that comprise their employment systems.

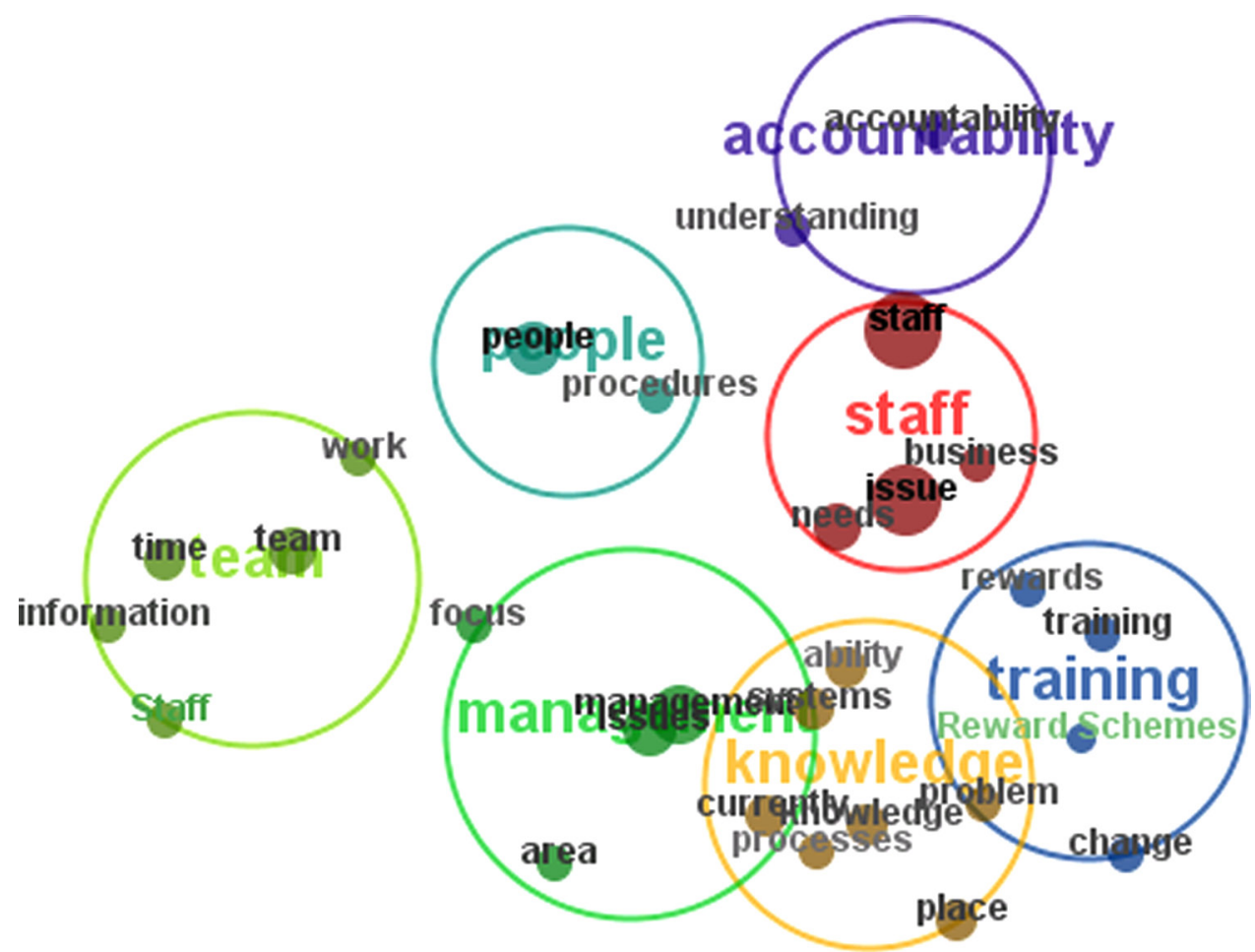

Figure 2. Leximancer Map of Manager Data Note: All concepts shown, theme size at $35 \%$

\section{CEO views}

The fourth analytical step explored the qualitative data from the CEO surveys. As shown in Figure 2, noticeable differences between employee and CEO views emerged. While CEOs viewed staff as centrally important to their business, their focus was on operational and compliance HRM issues, such as training for the current job, putting stronger control systems in place and filling staff and/ or knowledge gaps. This profoundly functional approach positioned employees operationally rather than as strategic and/or dynamic partners in firm performance. Furthermore, although employees emphasized the importance of participation and having a voice in the decisions and strategies of the firm, CEOs did not identify this as important. We also compared the data gathered 
from CEOs of high- and low-performing firms. While the issues raised by the respondents from these two datasets were markedly different, there was no evidence that they viewed issues from completely different perspectives, in marked contrast to employee responses.

The fifth and final step of our analysis explored the links between the data and the literature pertaining to operational success in small firms. First, we compared our aggregate dimensions (see Table 1) with the literature on employment systems. Each dimension was mapped to an aspect of the literature. Our aggregate dimensions corresponded to HPWS (Lawler and Benson, 2003): trust (Barnard and Rodgers, 2000), teamwork (Guest and Hoque, 1994), participation (Arthur, 1994), organizational learning orientation and employee skill development (Ahmad and Schroeder, 2003; Neal et al., 1995), performance systems (Wright et al., 2003), flexible work practices (Richard and Johnson, 2001) and high commitment (Arthur, 1994).

Second, we analysed the relationship between employee systems (from an employee perspective) and organizational (i.e. operationally focused) success (from the CEO's perspective). The patterns revealed interrelationships among clusters of functional activities, engagement, participation and organizational support. Employees clearly described the impact of employment systems on creating an environment where they could engage and contribute, and saw this as delivering positive organizational outcomes. Informality emerged as a thread through many of the comments from employees in high-performing firms. For example, informality allowed staff to adjust tasks to suit their needs as well as those of customers. Furthermore, work arrangements that were flexible and collegial supported mutual adjustments beyond formal work systems. The repetition of similar clustering pattern contributed to the mapping of practices described in the literature as 'highperformance work systems' (US Department of Labor, 1993: 1).

The employees' perspectives in high- and low-performing firms were noticeably different from one another. High-performing firms exhibited a 'virtuous' pathway similar to those reported in HPWS, comprising positive employee attitudes and behaviours. In these firms, the respondents' comments provide evidence of the interconnections among job satisfaction and affective commitment ('I enjoy coming to work'), individual behaviour ('I understand the processes in place to achieve efficiencies and use them successful') and collective capability ('It is important to work as a team moving forward together. This aspect is improving with more knowledge gained by us all as to how to become more efficient in planning'). Furthermore an improvement oriented mindset is evident ('It can always improve, but new systems have been introduced that should produce better outcomes').

Employees in the low-performing firms reported almost the opposite perceptions of employment systems. Participants commented on low job satisfaction ('This employer's lack of direction and delegation of work results in some staff not working efficiently'), the lack of committed and skilled staff ('This attitude towards staff makes it hard to keep well trained staff and a positive attitude'), and misalignment between staff, behaviour and strategy ('The small team helps, but I feel that we still need more structure and systems in place to really shine'. Employees identified areas they believed would improve performance ('a number of improvements can be achieved to better utilize technology and environmental processes to lead to greater efficiencies'). In these firms, negative linkages emerged between job satisfaction, a lack of commitment, both behavioural and affective and capability development, which collectively undermined performance in these firms.

Our exploratory analysis shows that small firm employment systems vary considerably; however, these findings confirm existing empirical support for the strategic value of employment systems within small firms. In sum, important differences emerged between high- and lowperforming small firms based on clusters of informal employment practices in a context of participative and mutually supportive cultures. Successful firms had more highly rated people 
management processes, and work systems were seen by employees as drivers of success. CEO views were less discriminating regarding potential people management differences. These findings and their implications are now discussed.

\section{Discussion}

Our discussion integrates the above levels of analysis with extant research and elaborates the issues arising from differing perspectives on the employment systems of these small firms. Three major themes are highlighted.

\section{Comparison of high- and low-performing firms}

Stark differences emerged in the attitudes expressed by employees relating to several HR practices in high-performing firms from employees in low-performing firms. Better-performing firms were rated highly on all aspects of people management systems. While support, engagement and participation were central concepts in all firms, this was emphasized in higher performing firms. Furthermore, subjective experiences of work related to a cluster of effective objective practices. Employees in highperforming firms specifically commented on flexible work practices, viable career paths, clear requirements, constructive feedback, positive rewards and recognition, access to training and development, a supportive culture, perception of organizational support, high involvement and good communication. In contrast, employees in poor-performing firms referred to an absence of support, engagement and participation. Attention was drawn to inflexible work practices, lack of career paths, poor or non-existent feedback, limited recognition, little opportunity for training and development, a culture of fear, lack of support (organizational or supervisory), no or low level of involvement and poor communication.

Our results reinforce Edwards and Ram's (2010) and Nguyen and Bryant's (2004) work, which argues that small firm advantage is built upon informal employment systems and distinct employee capabilities. In addition, we highlight the importance of participation to leverage employee contribution and commitment. Our small firms demonstrated a practical and flexible approach to employment systems that supported the business strategy, consistent with Baron et al. (1996) and Hayton (2003). Critical factors appear to reside in employees' perceptions with regard to a small number of informal employment practices and opportunities to participate within a positive organizational culture.

\section{Differentiating views of CEOs and employees}

Our inclusion of employee perspectives and focus on their experience of employment systems addresses the imbalance created by reporting purely managerial views (Wood and Wall, 2007). Methodologically, the use of employee perspectives on employment systems, along with those of CEOs on performance, reduces the likelihood of common method and common source variance (Wall and Wood, 2005). The differences between CEO and employee views are striking in that they were counterintuitive. Employees were more positive about employment practices and generally had a more strategic view of the role that they could play in improving organizational outcomes. For example, they were able to provide suggestions regarding areas of improvement to cost-effectiveness. The results demonstrate that employee participation, involvement and engagement are central to systemic contributions to firm performance, and that employee perspectives on these are linked to firm success. 
The results also emphasize the importance of adopting broader perspectives on firm performance. Just as the start-up literature has shifted from founder to founding teams (e.g. Beckman et al., 2007; Cooney, 2005), the links between employment systems and their drivers need to extend beyond the CEO. In our study, CEO views appeared to lack insight into the value of informal practices that comprise employment systems. The strategy literature has recognized increasingly that the systems and processes that contribute to competitive advantage are better captured in a consideration of the entire workforce (Mueller, 1996; Wright et al., 1998). Particularly in small firms, employees embody the knowledge, learning, innovation and engagement in organizational routines that may be central to the firm's capabilities (Helfat, 2000). Our data support the engagement of small firm staff to provide a competitive advantage based on sound, informal HR management and enhanced participation and engagement.

\section{Small firms and employment systems}

Even at the level of first reviews of Leximancer coding, we were surprised at the high levels of correspondence between the naturally emerging attributions of employees to firm success and the key practices identified in the HPWS and organizational performance literature (Cooke, 2001): for example, the emphasis on teamwork and participation as distinct issues (Arthur, 1994; Guest and Hoque, 1994). Therefore, we compared the data-driven aggregate dimensions with the HPWS literature. HPWS bundle employee skill development, collaborative workplace problem-solving and employee commitment and citizenship behaviour (Colvin, et al., 2001). Although we did not use HPWS to drive the design or analysis, it emerged as a supportive framework for the penultimate stages of analysis.

Our findings indicate that employment systems in high-performing small firms shared many attributes linked to organizational performance through employees who are aware of the practices that they believe will make the firm more successful, are highly committed to enacting those practices, and demonstrate quality consciousness. More importantly, our results reinforce the importance of participation mechanisms to enable and support enhanced firm performance. Firms with effective voice and participation, complemented by robust HR systems, showed enhanced organizational performance. Participation was an important differentiator for these small firms, yet it often has been omitted or underplayed in the HPWS literature (Wood and Wall, 2007).

Accordingly, we adopted a broader employment systems approach that acknowledges a range of options that small firms use to connect work arrangements with firm goals (Osterman, 1987), rather than adopting a prescriptive HPWS approach. The emphasis is not on resources themselves but on how small firms can use them in creative ways, such as informal yet effective employment practices to compete successfully in markets often dominated by other (larger) firms (Gilman and Edwards, 2008; Godard, 2002; Thompson and Heron, 2005). Flexible systems can engender employee commitment and, if used correctly, may facilitate quick decision-making and problemsolving, leading to competitive advantage (Marlow et al., 2010), despite Ram et al. (2001) warning that informality can mask exploitation.

\section{Conclusion}

This paper has sought to enhance our understanding of the relationship between employment practices and performance in small firms. Thus, our first theoretical contribution stems from a comparison of employee responses in better and poorer performing firms. The sharply contrasting views of employees on performance were mirror images of employment practice and engagement. Our 
second contribution arises from our focus on employees' perspectives in contrast with CEO views. The CEO views are less differentiated and, ironically, less strategic than those of employees. Our third contribution is support for the concept of HPWS from employee perspectives and their potential theoretical contribution to understanding the employment systems of successful small firms. A fourth contribution can be found in our research approach, which not only highlights the importance of multiple views when researching employment systems in small firms, but also introduces a systematic approach to data collection and analysis. In concluding, we suggest that tailored employment systems that promote organizational performance at the employee level may be more appropriate for small firm performance, and that employee perspectives are important to fully assess employment systems.

While research suggests that there is no simplistic optimum approach for small firms to follow in organizing their employees, and that configurations would evolve as firms grow (Drummond and Stone, 2007), our data reinforce the importance of aggregated clusters of employment and management activities rather than any single practice (Gilman and Edwards, 2008). Better performing firms were rated more highly on all aspects of their people management systems. In contrast, employees characterized lower performing firms as falling at the opposite end of continua with regards to aspects of traditional HR functions, as well as trust, fairness, communication and participation, which evokes comparison with the HPWS literature and its emphasis on clusters of practices. However, recent developments in HPWS have highlighted the importance of intermediate outcomes, including employee skill development, collaborative workplace problem-solving and an emphasis on employee commitment and citizenship behaviour (Colvin et al., 2001). All of these intermediate outcomes are empirically linked not only to HR practices and organizational performance, but also to workplace reciprocity and effective interactions with managers (Ilies et al., 2007; Lavelle et al., 2009; Podsakoff et al., 1990) and perceived organizational support (Randall et al., 1999).

Whether we rely on HPWS or approaches that advocate good management practices for a particular context (Paauwe, 2004), our findings underscore the importance of employee voice and participation, which form the often-overlooked core of strategic approaches to HRM (see Beer et al., 1984) as well as HPWS (Wood and Wall, 2007). This has important implications both for research on small firms, which has focused primarily on HR functions, and for managerial practices in small firms, where informality is assumed to encompass more open and participative structures. Both HPWS and strategic approaches to HRM are usually associated with more formal and prescribed HRM structures. Nguyen and Bryant (2004) have documented that HR formality increases with firm size and is linked to managerial perceptions of firm performance and, by implication, that HR formality and firm performance may be linked, while noting considerable debate in this arena. Our results may throw a slight different light on the formality-performance debate and on Nguyen and Bryant's (2004) findings. As we note earlier, CEO views of HR performance and culture are far less discriminating and predictive than the views of employees. Unlike CEOs, employees and their immediate supervisors are immersed in the informal systems and processes that allowed the better-performing firms to succeed and hindered the lower performing firms. CEOs in both higher and lower performing firms often see employees as problems: we might hypothesize that as firms grow and staff numbers increase, CEOs become more concerned about, and more removed from, informal systems in their firm. If their firms are perceived to be performing well, CEOs have the institutional and resource 'slack' to invest in more formalized systems, including formalizing HR systems. Thus, both size and CEO assessment of performance may precede HR formalization - at least initially. If researchers of HR formalization (e.g. Marlow and Patton, 2002; Wilkinson, 1999) are correct about the benefits of such a move, it would become self-reinforcing: the systems would become more efficient, improving productivity although 
potentially compromising flexibility, and CEOs would have greater access to the performance of HR systems, even if staff found them less workable. However, we would caution that any benefits of formalization must accommodate employee voice and participation. The findings suggest that this is an essential element of the 'balancing act' in resolving the inherent tensions in the small firm between HR formality and informality (Gilman and Edwards, 2008).

Both the centrality of voice and participation, and the lack of CEO insight into these phenomena, highlight the third contribution of this research. Most aspects of employee commitment, communication, interaction and participation are assessed, both in research and practice, at the employee level. Therefore, it follows that researching HRM in small firms requires tapping into employee perspectives. This is reinforced by the acknowledged informality of HR systems in small firms: informal HR is a flexible set of practices, understood best by those who enact them. This criticism is not limited to small firms, of course. Drummond and Stone (2007) have emphasized the importance of gaining employee perspectives on all employment systems, and there is a lengthy research record documenting the divergence of employee views of the employment relationship. However, our research demonstrates that this is not just a difference in perspective from both sides of a relationship. With regards to informal HR systems, employees appear to effectively understand the systems and differentiate, and CEOs do not. Thus, CEO-centric research approaches leave those with the greatest insight outside the research frame. While this insight is not limited to the less formalized employment structures of small firms, within this frame the absence of employee perspectives limits our understanding of both HR systems and performance drivers.

\section{Limitations of the study}

We recognize the limitations of our study as exploratory with a non-random sample of small firms and, therefore, subject to both self-selection and self-report biases. Although this is not uncommon in small firm research, it limits the generation of theory. Acknowledging these limits, we attempted to reduce these biases by ensuring representativeness of the sample and anonymity of responses. Using a split-sample analytical framework, rather than a priori benchmarks, allowed us to test conservatively for differences. The use of Leximancer, which generates categories based on the language of respondents alone, also provided a limiter to research framing or expectations regarding key themes and relationships between concepts. However, the use of a systematic approach during data analysis, which utilized the best features of manual content analysis and automated text analysis, were useful in managing the difficulties resulting from this limitation.

\section{Directions for further research}

Future research may link organizational performance, people management practices and the dimensions associated with employment systems more explicitly, by developing instruments to tap these phenomena in a broader array of small firms. At the same time, we must refine our ability to capture 'performance' in the small firm more precisely and to assess employment systems in small firms, incorporating formality/informality and voice and participation more explicitly.

From a practice perspective, small firm CEOs are well advised to engage with employee perspectives and align firm goals with informal, flexible employment practices, rather than emulating HRM models designed for large firms. The implications of this research for management practice rest primarily on managers of small firms understanding the importance of communication, participation and voice in their firms as they grow. There are established bodies of practice to support participation 
and engagement, and these may be prerequisites or co-requisites to HR formalization as the firm grows and evolves. In addition, our findings may suggest that small firm managers who are seeking greater formalization might benefit from incorporating formalized feedback mechanisms (e.g. 'Best Place to Work' surveys, etc.), which may help to keep participation and voice structures central as other processes formalize. A more comprehensive view of employment systems overall might be encouraged in small firm CEOs, who appear to adopt distinctly operational views of 'people management' in their firms, despite acknowledging the importance of the capabilities and attitudes of their staff. Overall, our results reinforce Schneider's maxim: the people make the place (Schneider, 1987).

\section{Funding}

Our industry partner is a multinational HR consultant. While there is some potential bias due to the relationship of the consultant and the CEOs, there is no relationship with employees, the focus of this research. Furthermore, none of the researchers had any relationship with any respondents, and received no funding for the project.

\section{Acknowledgments}

The authors would like to acknowledge Louise Broekman for her valuable contribution as industry partner to this project.

\section{Note}

1. CEOs self-selected into a process with the industry partner to explore business improvement strategy, in order to identify internal risks and opportunities. The average firm size was 20 full-time employees.

\section{References}

Ahmad S and Schroeder RG (2003) The impact of human resource management practices on operational performance: Recognising country and industry differences. Journal of Operations Management 21(1): 19-34. Allen MR and Wright P (2007) Strategic Management and HRM. In: Boxall P, Purcell J and Wright P (eds) The Oxford Handbook of Human Resource Management. Oxford: Oxford University Press, 88-107.

Appelbaum E, Bailey T, Berg P and Kalleberg A (2000) Manufacturing Advantage. Ithaca, NY: Cornell University Press.

Arthur JB (1994) Effects of human resource systems on manufacturing performance and turnover. Academy of Management Journal 37(3): 670-687.

Barnard ME and Rodgers RA (2000) How are internally oriented HRM policies related to high-performance work practices? Evidence from Singapore. International Journal of Human Resource Management 11(6): $1017-1046$.

Baron JN, Burton MD and Hannan MT (1996) The road taken: The origins and evolution of employment systems in emerging high-technology ocmpanies. Industrial and Corporate Change 5(2): 239-276.

Baron JN, Burton MD and Hannan MT (1999) Engineering bureaucracy: The genesis of formal policies, positions and structures in high-technoogy firms. Journal of Law, Economics and Organization 15(1): 1-41.

Beckman CM, Burton MD and O'Reilly C (2007) Early teams: The impact of team demography on VC financing and going public. Journal of Business Venturing 22(2): 147-173.

Beer M, Spector B, Lawrence D, Quinn Mills D and Walton R (1984) Managing Human Assets. New York: The Free Press.

Bowen DE and Ostroff C (2004) Understanding HRM-firm performance linkages: The role of the 'strength' of the HRM system. Academy of Management Review 29(2): 203-221. 
Boxall P and Purcell J (2000) Strategic human resource management: Where have we come from and where should we be going? International Journal of Management Review 2(2): 183-203.

Broekman L (2009) Star performance: Maximize planning. Business Franchise Magazine, 6 March, p. 100.

Brown DM and Laverick S (1994) Measuring corporate performance. Long Range Planning 27(4): 89-98.

Cardon MS and Stevens CE (2004) Managing human resources in small organizations: What do we know? Human Resource Management Review 14(3): 293-323.

Carlson DS, Upton N and Seaman S (2006) The impact of human resource practices and compensation design on performance: An analysis of family-owned SMEs. Journal of Small Business Management 44(4): 531-543.

Cassell C, Nadin S, Gray M and Clegg C (2002) Exploring human resource practices in small and medium sized enterprises. Personnel Review 31(6): 671-693.

Chan YE, Bhargava N and Street CT (2006) Having arrived: The homogeneity of high-growth small firms. Journal of Small Business Management 44(3): 426-440.

Chang E (2005) Employees' overall perception of HRM effectiveness. Human Relations 58(4): 523-544.

Ciavarella MA (2003) The adoption of high-involvement practices and processes in emergent and developing firms: A descriptive and prescriptive approach. Human Resource Management 42(4): 337-356.

Clark B (2002) Measuring performance: The marketing perspective. In: Neely A (ed.) Business Performance Measurement: Theory and Practice. Cambridge: Cambridge University Press, 22-40.

Colvin AJS, Batt R and Katz HC (2001) How high performance human resource practices and workforce unionization affect managerial pay. Personnel Psychology 54(4): 903-934.

Cooke FL (2001) Human resource strategy to improve organizational performance: A route for firms in Britain. International Journal of Managament Review 3(4): 321-339.

Corley K and Gioia DA (2004) Identity ambiguity and change in the wake of a corporate spin-off. Administrative Science Quarterly 49(2): 173-208.

Cummings S and Daellenbach U (2009) A guide to the future of strategy? The history of long range planning. Long Range Planning 42(2): 234-263.

Darr A (2003) Control and autonomy among knowledge workers in sales: An employee perspective. Employee Relations 25(1): 31-41.

Davies I, Green P, Rosemann M, Indulska M and Gallo S (2006) How do practitioners use conceptual modeling in practice? Data Knowledge and Engineering 58(3): 358-380.

Deshpande SP and Golhar DY (1994) HRM practices in large and small manufacturing firms: A comparative study. Journal of Small Business Management 32(2): 49-56.

Dess GG, Lumpkin GT and Covin JG (1997) Entrepreneurial strategy making and firm performance: Tests of contingency and configurational models. Strategic Management Journal 18(9): 677-695.

Drummond I and Stone I (2007) Exploring the potential of high performance work systems in SMEs. Employee Relations 29(2): 192-207.

Duberley JP and Walley P (1995) Assessing the adoption of HRM by small and medium-sized manufacturing organisations. International Journal of Human Resource Management 4(4): 891-909.

Edwards P and Ram M (2010) HRM in small firms: Respecting and regulating informaltiy. In: Wilkinson A, Bacon N, Redman T and Snell S (eds) The Sage Handbook of Human Resource Management. London: Sage, 524-540.

Galbreath J and Galvin P (2006) Accounting for performance variation: How important are intangible resources? International Journal of Organizational Analysis 14(2): 150-170.

Galbreath J and Galvin P (2008) Firm factors, industry structure and performance variation: New empirical evidence to a classic debate. Journal of Business Research 61(2): 109-117.

Garnsey E, Stam E and Heffernan P (2006) New firm growth: Exploring processes and paths. Industry and Innovation 13(1): 1-20. 
Gerhart B, Wright PM, McMahan GC and Snell SA (2000) Measurement error in research on human resources and firm performance: How much error is there and how does it influence effect size estimates? Personnel Psychology 53(4): 803-834.

Gilman MW and Edwards PK (2008) Testing a framework of the organization of small firms: Fast-growth, high-tech SMEs. International Small Business Journal 26(5): 531-558.

Glancey K (1998) Determinants of growth and profitability in small entrepreneurial firms. International Journal of Entrepreneurial Behaviour and Research 4(1): 18-27.

Godard J (2002) Institutional environments, employer practices, and states in liberal market economies. Industrial Relations 41(2): 249-286.

Graham ME and Tarbell LM (2006) The importance of the employee perspective in the compentency development of human resource professionals. Human Resource Management 45(3): 337-355.

Grant D and Shields J (2002) In search of the subject: Researching employee reactions to human resource management. Journal of Industrial Relations 44(3): 313-334.

Greasley K, Bryman A, Dainty A, Price A, Naismith N and Soetanto R (2008) Understanding empowerment from an employee perspective: What does it mean and do they want it? Team Performance Management 14(1-2): 39-55.

Grech MR, Horberry T and Smith A (2002) Human error in maritime operations: Analysis of accident reports using the Leximancer tool. Paper presented at the Human Factors and Ergonomics Society 46th Annual Meeting, Baltimore, MD, 30 September-4 October.

Guest D (2001) Human resource management: When research confronts theory. International Journal of Human Resource Management 12(7): 1092-1106.

Guest D (2002) Human resource management, corporate performance and employee wellbeing: Building the worker into HRM. Journal of Industrial Relations 44(3): 335-358.

Guest D and Hoque K (1994) The good, the bad and the ugly: Employee relations in new non-union workplaces. Human Resource Management Journal 5(1): 1-14.

Hartarska V and Gonzalez-Vega C (2006) What affects new and established firms' expansion? Evidence from small firms in Russia. Small Business Economics 27(2-3): 195-206.

Hayton JC (2003) Strategic human capital management in SMEs: An empirical study of entrepreneurial performance. Human Resource Management 42(4): 375-391.

Helfat CE (2000) Guest editor's introduction to the special issue: the evolution of firm capabilities. Strategic Management Journal 21(10-11): 955-959.

Henemann RL and Tanskey JW (2002) Human resource management models for entrpreneurial opportunity: Existing knowledge and new directions. In: Katz J and Wellbourne TM (eds) Managing People in Entrepreneurial Organizations, Vol. 5. Amsterdam: JAI Press, 55-82.

Ho M, Wilson M and Chen S (2010) HRM in New Zealand biotechnology SMEs: Emergence of employment systems through entrepreneurship. International Journal of Human Resource Management 21(3): 313-336.

Hornsby JS and Kuratko DK (1990) Human resource management in small business: Critical issue for the 1990s. Journal of Small Business Management 28(July): 9-18.

Huselid MA (1995) The impact of human resource management practices on turnover, productivity and corporate financial performance. Academy of Management Journal 38(3): 635-672.

Ilies R, Nahrgang JD and Morgeson FP (2007) Leader-member exchange and citizenship behaviour: A metaanalysis. Journal of Applied Psychology 92(1): 269-277.

JRA (2008) Australian Workplace Survey. City of Brisbane: JRA.

Kabanoff B and Brown S (2008) Knowledge structures of prospectors, analysers and defenders: Content, structure, stability and performance. Strategic Management Journal 29(2): 149-171. 
Knight G (2000) Entrepreneurship and marketing strategy: The SME under globalization. Journal of International Marketing 8(2): 12-32.

Lavelle J, Brockner J, Konovsky M, Price K, Henley A, Taneja A, et al. (2009) Commitment, procedural fairness and organizational citizenship behaviour: A multifoci analysis. Journal of Organizational Behaviour 30(3): 337-357.

Lawler EE and Benson GS (2003) Employee involvement: Utilization, impacts and future prospects. In: Holman DT, Wall TD, Clegg CW, Sparrow P and Howard A (eds) The New Workplace: A Guide to the Human Impact of Modern Working Practices. London: Wiley, 155-173.

Lebas M and Euske K (2002) A conceptual and operational delineation of performance. In: Neely A (ed.) Business Performance Measurement: Theory and Practice. Cambridge: Cambridge University Press, $65-79$.

McGee JE and Sawyerr OO (2003) Uncertainty and information search activities: A study of owner-managers of small high-technology manufacturing firms. Journal of Small Business Management 41(4): 385-401.

Macky K and Boxall P (2007) The relationship between 'high-performance work practices' and employee attitudes: An investigation of additive and interaction effects. International Journal of Human Resource Management 18(4): 537-567.

Marlow S (2006) Human resource management in smaller firms: A contradiction in terms? Human Resource Management Review 16(4): 467-477.

Marlow S and Patton D (2002) Minding the gap between employers and employees: The challenge for ownermanagers of smaller manufacturing firms. Employee Relations 24(5): 523-539.

Marlow S, Taylor S and Thompson A (2010) Informality and formality in medium-sized companies: Contestation and synchronization. British Journal of Management 21(4): 954-967.

Mazzarol T (2003) A model of small business HR growth management. International Journal of Entrepreneurial Behaviour and Research 9(1): 27-49.

Middleton S, Liesch PW and Steen J (2011) Organizing time: Internationalization narratives of executive managers. International Business Review 20(2): 136-150.

Mueller F (1996) Human resources as strategic assets: An evolutionary resource based theory. Journal of Management Studies 33(6): 757-785.

Neal JA, Tromley CL, Lopez E and Russell J (1995) From incremental change to retrofit: Creating highperformance work systems. Academy of Management Executives 9(1): 42-54.

Nguyen TV and Bryant SE (2004) A study of the formality of human resource management practices in small and medium-size enterprises in Vietnam. International Small Business Journal 22(6): 595-618.

Ohl R (2008) Computer Supported Argument Visualization: Modeling Wicked Problems. Brisbane: Griffith University.

Osterman P (1987) Choice of employment systems in internal labor markets. Industrial Relations 26(1): $46-67$.

Paauwe J (2004) HRM and Performance: Achieving Long-term Viability. Oxford: Oxford University Press.

Podsakoff PM, MacKenzie SB, Moorman RH and Fetter R (1990) Transformational leader behaviours and their effects on followers' trust in their leader, satisfaction and organizational citizenship behaviours. Leadership Quarterly 1(2): 107-142.

Podsakoff PM, MacKenzie SB, Podsakoff NP and Lee J (2003) Common method biases in behavioural research: A critical review of the literature and recommended remedies. Journal of Applied Psychology 88(5): 879-903.

Purcell J (1999) High commitment management and the link with contingent workers: Implications for strategic human resource management. In: Wright P, Dyer L, Boudreau J and Milkovich G (eds) Research in 
Personnel and Human Resources Management (Supplement 4: Strategic Human Resources Management in the Twenty-First Century). Stamford, CT: JAI Press, 239-257.

Ram M, Edwards P, Gilman M and Arrowsmith J (2001) The dynamics of informality: Employment relations in small firms and the effects of regulatory change. Work, Employment and Society 15(4): 845-861.

Ramsay H, Scholarios D and Harley B (2000) Employees and high-performance work systems: Testing inside the black box. British Journal of Industrial Relations 38(4): 501-531.

Randall M, Cropanzano R, Bormann C and Birjulin A (1999) Organizational politics and organizational support as predictors of work attitudes, job performance and organizational citizenship behaviour. Journal of Organizational Behaviour 20(2): 159-174.

Richard OC and Johnson NB (2001) Strategic human resource management effectiveness and firm performance. International Journal of Human Resource Management 12(1): 299-310.

Rockmore BW (1996) Business investment strategy and firm performance: A comparative examination of accounting and market-based measures. Managerial Finance 22(8): 44-56.

Rutherford MW, Buller PF and McMullen PR (2003) Human resource management problems over the life cycle of small to medium-sized firms. Human Resource Management 42(4): 321-335.

Schneider B (1987) The people make the place. Personnel Psychology 40(3): 437-453.

Sels L, De Winne S, Maes J, Delmotte J, Faems D and Forrier A (2006) Unravelling the HRM-performance link: Value-creating and cost-increasing effects of small business HRM. Journal of Management Studies 43(2): 319-342.

Smith AE (2003) Automatic extraction of semantic networks from text using Leximancer. Paper presented at the North American Chapter of the Association for Computational Linguistics - Human Language Technologies, Edmonton, Canada, May-June.

Smith AE and Humphreys MS (2006) Evaluation of unsupervised semantic mapping of natural language with Leximancer concept mapping. Behaviour Research Methods 38(2): 262-279.

Takeuchi R, Chen G and Lepak DP (2009) Through the looking glass of a social system: Cross-level effects of high-performance work systems on employees' attitudes. Personnel Psychology 62(1): 1-29.

Tanskey JW and Henemann RL (2003) Guest editor's notes: Introduction to the special issue in human resource management in SMEs: A call for more research. Human Resource Management 42(4): 299-302.

Thompson M and Heron P (2005) The difference a manager can make: Organizational justice and knowledge worker commitment. International Journal of Human Resource Management 16(3): 383-404.

Tsui A and Wang D (2002) Employment relationships from the employer's perspective: Current research and future directions. In: Cooper CL and Robertson IT (eds) International Review of Industrial and Organizational Psychology. Chichester: Wiley, 77-114.

US Department of Labor (1993) High Performance Work Practices. Washington, DC: US Department of Labor.

Verreynne M and Meyer D (2010) Making strategy at different stages of the industry life cycle: Relationships with small firm performance. Small Business Economics 35(4): 399-416.

Wall TD and Wood SJ (2005) The romance of human resource management and business performance and the case for big science. Human Relations 58(4): 429-462.

Way SA (2002) High performance work systems and intermediate indicators of firm performance within the US business sector. Journal of Management 26(6): 765-785.

Web D and Pettigrew A (1999) The temporal development of strategy: Patterns in the U.K. Insurance industry. Organization Science 10(5): 601-621.

Welbourne TM and Andrews AO (1996) Predicting the performance of initial public offerings: Should human resource management be in the equation? Academy of Management Journal 39(4): 819-919. 
Wilkinson A (1999) Employment relations in SMEs. Employee Relations 21(3): 206-217.

Wood SJ and Wall TD (2007) Work enrichment and employee voice in human resource management performance studies. International Journal of Human Resource Management 18(7): 1335-1372.

Wright PM, McMahan G and McWilliams A (1994) Human resources and sustained competitive advantage: A resource-based perspective. International Journal of Human Resource Management 5(2): 301-326.

Wright PM, McMahan GC, McCormick B and Sherman WS (1998) Strategy, core competence and HR involvement as determinants of HR effectiveness and refinery performance. Human Resource Management 37(1): 17-29.

Wright PM, Gardner TM and Moynihan LM (2003) The impact of HR practices on the performance of business units. Human Resource Management Journal 13(3): 21-36.

Martie-Louise Verreynne is a senior lecturer in strategy at the University of Queensland Business School. She has presented numerous papers at national and international conferences and has written several book chapters and articles in leading journals. She has received various awards and grants, including three best paper awards in the strategy and public sector areas in the last four years from the Australian and New Zealand Academy of Management. Her current work is in the areas of small firm growth, strategy, entrepreneurship and innovation.

Polly Parker is MBA Director and Associate Professor at the University of Queensland Business School, where she teaches leadership and human resource management. She has a lifelong interest in teaching and learning which she has applied in both academic and corporate settings. She is originator and co-developer of the Intelligent Career Card Sort TM, which is used worldwide and translated into several languages. Her current interests reside in adult development and her research publications are related to the areas of career management and leadership development and development of HR in organizations.

Marie Wilson is Professor of Management and Academic Dean of Griffith Business School, Griffith University. Her research focuses on the interaction between organizational citizenship behaviour and professional identity, as well as the links between entrepreneurship and work systems. Marie combines a 20-year academic career with over 20 years in the information technology industry, including senior leadership roles in start-ups, spin-offs and small enterprises. 
Appendix: Employee Questionnaire Items

\begin{tabular}{|c|c|c|}
\hline Item topic & Number of questions & Example question \\
\hline Teamwork & 3 & $\begin{array}{l}\text { How satisfied are you with team } \\
\text { motivation, (rating scale)? } \\
\text { Please comment. }\end{array}$ \\
\hline Communication & 3 & $\begin{array}{l}\text { How satisfied are you with the quality } \\
\text { of communication (rating scale)? } \\
\text { Please comment. }\end{array}$ \\
\hline Management and leadership & 4 & $\begin{array}{l}\text { How satisfied are you with the } \\
\text { effectiveness of your management } \\
\text { team (rating scale)? } \\
\text { Please comment. }\end{array}$ \\
\hline Pay and rewards & 3 & $\begin{array}{l}\text { How satisfied are you with pay and } \\
\text { bonuses (rating scale)? } \\
\text { Please comment. }\end{array}$ \\
\hline Training and development & 3 & $\begin{array}{l}\text { How satisfied are you with training } \\
\text { and development for your job } \\
\text { (rating scale)? } \\
\text { Please comment. }\end{array}$ \\
\hline Work design and environment & 5 & $\begin{array}{l}\text { How satisfied are you with } \\
\text { flexibility in work arrangements } \\
\text { (rating scale)? } \\
\text { Please comment. }\end{array}$ \\
\hline Planning and strategy & 3 & $\begin{array}{l}\text { How satisfied are you with knowing } \\
\text { how the business is performing and } \\
\text { future direction (rating scale)? } \\
\text { Please comment. }\end{array}$ \\
\hline Culture & 4 & $\begin{array}{l}\text { How satisfied are you with honesty } \\
\text { and integrity, (rating scale)? } \\
\text { Please comment. }\end{array}$ \\
\hline Customer focus & 3 & $\begin{array}{l}\text { How satisfied are you with your } \\
\text { ability to satisfy customer needs } \\
\text { (rating scale)? } \\
\text { Please comment. }\end{array}$ \\
\hline
\end{tabular}

